\title{
Fatty Acids Profile, Physicalchemical Properties and Minerals with Quantify Indicador of Astrocaryum aculeatum Pulp Oil
}

\author{
Bernardo M. Linhares ${ }^{1}$, Ana Marcia D. C. Costa ${ }^{1}$, Herliana D. F. Abreu ${ }^{1}$, Ana Cristina G. Reis de Melo ${ }^{2}$, \\ Pedro R. E. Ribeiro ${ }^{2}$, Ismael F. Montero ${ }^{3}$, Antonio A. Melo Filho ${ }^{1,3}$ \& Ricardo C. Santos ${ }^{4}$ \\ ${ }^{1}$ Federal University of Roraima, Postgraduate Program in Chemistry, Campus Paricarana, Boa Vista, RR, Brazil \\ ${ }^{2}$ Federal University of Roraima, Postgraduate Program in Natural Resources, Campus Paricarana, Boa Vista, RR, \\ Brazil \\ ${ }^{3}$ Federal University of Roraima, Postgraduate Program in Biotechnology and Biodiversity, Campus Paricarana, \\ Boa Vista, RR, Brazil \\ ${ }^{4}$ Universidade Federal de Roraima, National Postdoctoral Program of CAPES, PNPD/CAPES, Associated to the \\ Postgraduate Program in Agronomy of, POSAGRO/UFRR, Campus Cauamé, and to the Brazilian Agricultural \\ Research Corporation, Embrapa, Boa Vista, RR, Brazil \\ Correspondence: Ismael F. Montero, Federal University of Roraima, Postgraduate Program in Biotechnology and \\ Biodiversity, Campus Paricarana, CEP 69304-000, Boa Vista, RR, Brazil. E-mail: ismamontero@hotmail.com
}

Received: October 9, 2017

Accepted: November 7, $2017 \quad$ Online Published: November 15, 2017

doi:10.5539/jas.v9n12p352

URL: https://doi.org/10.5539/jas.v9n12p352

\begin{abstract}
The species Astrocaryum aculeatum (Arecaceae) is known in the Brazilian Amazon as tucumã, whose fruit is much appreciated by the population of the region, where its pulp, oleaginous, is the most consumed. Thus, the aim of this work was to perform a profile of fatty acids by GC-FID and minerals by ICP-OES of the oil of the pulp of the tucumã (A. aculeatum), as well as their physicochemical properties by ${ }^{1} \mathrm{H}$ NMR. The fruits were collected in Alto Alegre city, Roraima, Brazil. These were taken to the laboratory, sanitized and removing your pulp, submitted to the oven with air circulation at $50^{\circ} \mathrm{C}$ for $72 \mathrm{~h}$, the dried pulps were milled and sieved between 20-40 mesh. The pulp oil extraction was realized in Soxhlet with hexane for 6 hours (yield of 54.7\%). Were identified a total of 10 fatty acids, of these $23.8 \%$ are saturated fatty acids and $76.2 \%$ are unsaturated fatty acids: palmitic acid (10.4\%), stearic acid (4.9\%), oleic acid (64.2\%), linoleic acid (11\%) and linolenic acid (1\%). The physicochemical properties have a pulp oil acid index of $0.31 \mathrm{mg} \mathrm{KOH} \mathrm{g}^{-1}$, saponification of $190.39 \mathrm{mg} \mathrm{KOH} \mathrm{g}^{-1}$, iodine index of $85.97 \mathrm{mg} \mathrm{g}^{-1}$. Minerals such as in their available forms $\mathrm{K}\left(70.05 \mathrm{mg} \mathrm{L}^{-1}\right) \mathrm{Na}\left(30.30 \mathrm{mg} \mathrm{L}^{-1}\right), \mathrm{Ca}$ (20.13 $\left.\mathrm{mg} \mathrm{L}^{-1}\right)$ and $\mathrm{P}\left(20.07 \mathrm{mg} \mathrm{L}^{-1}\right)$ were observed in high concentrations. The Amazon tucumã is an oleaginous that deserves our attention because it is composed of essential fatty acids that are beneficial to the human health.
\end{abstract}

Keywords: Amazon, tucumã, oleic acid, calcium, GC-FID, ICP-OES

\section{Introduction}

With the growth and development of modern society, there is a need to search for new raw materials and new technologies that have viable characteristics and do not harm the environment, but meet the food needs and become an alternative source of renewable energy to meet the demands of the food and energy industry soon.

One of these raw materials is the Amazonas tucumã (Astrocaryum aculeatum) pulp because it is considered an important source of calories, proteins and vitamin A, so that a single fruit supplies the daily dose necessary for children and adults. When fresh it contains $3.5 \mathrm{mg}$ of $\beta$-carotene per each $100 \mathrm{~g}$, represents $22 \%$ of the fruit's weight, it contains $9 \%$ of protein and $55 \%$ of oil. In the digestion process, the carotene produces vitamin A, which is excellent for the health of the eye (Cymerys \& Ferreira, 2010).

The tuсumã fruit is probably an Amazon forest native and grows in the northern regions of Brazil and neighboring countries. It is a plant that belongs to the Arecaceae family, resistant to fire, for having the ability to regrow after the fire, it regenerates easily and reaches an average of 10 to 15 meters tall, having thorns along the trunk and its leaves. The fruit is rich in lipids and minerals. This palm is considered a pioneer and invasive plant of pastures, but it is also found in secondary and primary forests. It develops well on soils that are not solid. This species is recognized by several steppes (trunks) and yellow fruits, it blossoms between March and July and 
fruits in the rainy season, that is, from January to April. It has many utilities. Birds, fish, and other animals enjoy its fruits; young people make rings of its stones; children use the seeds when playing the Brazilian game peteca (Cymerys \& Ferreira, 2010).

According to Cavalcante (2010), the tucumã tree belongs to the Arecaceae family, and is also known as Amazonas tucumã because it is a palm that grows in a thicket with an average of four densely spiny stipes, being therefore considered as a promising species for the production of biodiesel in the Amazon, as it presents resistance to pests and diseases and fire, is not demanding on soil fertility and has good tillering capacity.

A typical palm tree produces about $50 \mathrm{~kg}$ per year even in weak soil regions (Cymerys \& Ferreira, 2010). As $A$. aculeatum and $A$. vulgare, it also grows in degraded and secondary vegetation areas. In general the tucumã trees produce from 2 to 3 bunches annually, but can reach more than 5 . Each bunch weighs between 10 and $30 \mathrm{~kg}$ and contains from 200 to 400 or more fruits. On average, a palm tree produces 750 fruits. Fruiting begins between 4 and 8 years (Shanley et al., 2010).

Studies performed by Ferreira et al. (2008) reported that the tucumã fruit is characterized by high lipid, caloric and $\beta$-carotene concentrations, as well as a considerable source of fiber and carbohydrates. The tucumã crude oil reported chemical properties close to those of palm oil. The quantification of the main fatty acids showed that its composition presents $29 \%$ of saturated and only $1 \%$ of polyunsaturated acids. Monounsaturated acids represent $68 \%$, having as mains representative the oleic acid which constitutes $67 \%$ of the chemical composition.

The realization of this research has become feasible because it was verified that quantitative and qualitative analyzes of oils extracted from the mesocarp and the almond of the fruits of this palm tree have already been carried out by several researchers, such as, for example, Pesce (1941), Bora et al. (2000), among others, they have shown that the oil content of this species of tucumã ranges between 33 to $47.5 \%$ in the pulp and 30 to $50 \%$ in the almond and shows that it has organoleptic characteristics that accredit them as edible fat of high value for the food industry, and there were no significant differences when compared to babaçu oil. The fats extracted are notable for their high content of saturated acids $(84 \%)$, trisaturated glycerides $(73 \%)$ and, for this reason, they were included by Hilditch (1941) in the group of eight exceptional fats.

It was based on these assumptions that the general objective of this study was to carry out a detailed analysis of the physico-chemical, mineral properties and biological tests of the tucumã pulp oil A. aculeatum, located in Alto Alegre municipality, Roraima. Regarding the specific objectives, the aim was: to quantify the oleaginous potential of the use of fruit pulp; to identify and quantify the major fatty acids present in the oil by GC-FID; to obtain information about the physicochemical characteristics through the ${ }^{1} \mathrm{H}$ NMR spectrum as: acidity index, iodine index, saponification index, relative density, metil point and quantify of majority minerals by ICP-OES.

\section{Method}

The tucumã ripe fruits were collected in Alto Alegre city, Roraima state, Brazil. They were divided into 3 samples, each sample with 12 tucumã fruits, after collected and separated, they were sent to the Laboratory of Environmental Chemistry in the Research Center of the Postgraduate Program in Chemistry from Federal University of Roraima. The tucumã samples were manually demolished with the help of a stainless steel knife, submitted to the oven at $50{ }^{\circ} \mathrm{C}$ for 72 hours, and milled and sieved between 20-40 Mesh. Each sample underwent the process of oil extraction in Soxhlet with hexane for 6 hours (Santos et al., 2015).

For the determination of the chemical composition of tucumã pulp oil by gas chromatography in the Chromatography Laboratory from Universidade Federal de Minas Gerais, where hydrolysis and methylation of the oil were made, in a $2 \mathrm{~mL}$ cryogenic tube, $\sim 12 \mathrm{mg}$ of the oil sample in $100 \mu \mathrm{L}$ of an ethanol $(95 \%) / 1 \mathrm{~mol} \mathrm{~L}^{-1}$ potassium hydroxide (5\%) solution was dissolved. After vortex agitation for $10 \mathrm{~s}$, the oil was hydrolyzed in a domestic microwave oven (Panasonic Piccolo) at power of $80 \mathrm{~W}$ (Power 2) for $5 \mathrm{~min}$. After cooling, $400 \mu \mathrm{L}$ of $20 \%$ hydrochloric acid, one tip of $\mathrm{NaCl}$ spatula $(\sim 20 \mathrm{mg})$ and $600 \mu \mathrm{L}$ of ethyl acetate were added. After vortex agitation for $10 \mathrm{~s}$ and standing for $5 \mathrm{~min}$, a $300 \mu \mathrm{L}$ aliquot of the organic layer was removed, placed in microcentrifuge tubes and dried by evaporation, thereby obtaining the free fatty acids. (Adapted from W. W. Christie). Subsequently, the free fatty acids were methylated with $100 \mu \mathrm{L} \mathrm{BF}_{3} /$ methanol (14\%) by heating for 10 $\min$ in a $60^{\circ} \mathrm{C}$ water bath. Then, they were diluted in $400 \mu \mathrm{L}$ methanol and analyzed by Gas Chromatography.

Aiming at the determination of fatty acids by gas chromatography, the analyzes were conducted on a HP7820A (Agilent) Gas Chromatograph equipped with flame ionization detector. EZChrom Elite Compact (Agilent) Data Acquisition Program (Agilent). A $15 \mathrm{~m} \times 0.22 \mathrm{~mm} \times 0.20 \mathrm{~mm}$ (SGE) column was used with temperature gradient: $80{ }^{\circ} \mathrm{C}, 0 \mathrm{~min}, 7{ }^{\circ} \mathrm{C} \min ^{-1}$ up to $220^{\circ} \mathrm{C}$; injector (split of $1 / 50$ ) at $250{ }^{\circ} \mathrm{C}$ and detector at $260{ }^{\circ} \mathrm{C}$. 


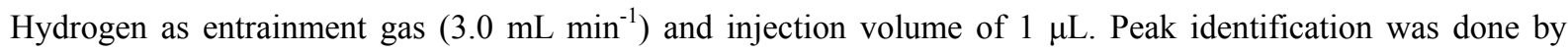
comparison with FAME $\mathrm{C}_{14}-\mathrm{C}_{22}$ methylated fatty acid standards (Supelco cat. No. 18917).

The tucumã oil was solubilized in $0.6 \mathrm{~mL}$ of deuterated chloroform, $\mathrm{CDCl}_{3}$, using trimethylsilane (TMS) as an internal standard and its spectrum was obtained by ${ }^{1} \mathrm{H}$ NMR $(500 \mathrm{MHz})$ of 11.7 Tesla from the Analytical Center of the University of São Paulo, under the following conditions: for the ${ }^{1} \mathrm{H}$ NMR the following acquisition parameters were used: pulse: $30^{\circ}$, relaxation time: $1 \mathrm{~s}$, acquisition time: $3,276 \mathrm{~s}$, scanning width: $10,000 \mathrm{~Hz}$, Line width: $0.152 \mathrm{~Hz} .128$ repetitions were accumulated for each free induced decay (FID) with a total time of $13.21 \mathrm{~s}$ To analyze the ${ }^{1} \mathrm{H}$ NMR spectrum and signal integrations, SpinWork 4.2.0 free software was used.

The determination of the relative density was determined by the use of a previously weighed pycnometer without sample, the mass being placed in the pycnometer with the temperature set at $25^{\circ} \mathrm{C}$. The relationship between the sample mass and the water mass at $25{ }^{\circ} \mathrm{C}$ presents the specific density (IAL, 2008). To carry out the determination of the melting point, the sample was placed in capillary, frozen and later placed in the apparatus of melting point MQAPF-302 with temperature variation of 0.1 in $0.1^{\circ} \mathrm{C}$.

To determine the physicochemical properties value by means of ${ }^{1} \mathrm{H}$ NMR, it was based on Equations (1-7), according to Reda (2004) and Reda and Carneiro (2006). The determination of the values of each variable, referring to Equations (1-7), is obtained by integrating each signal:

$$
\begin{gathered}
\text { Ap (Proton area })=(\mathrm{i}+\mathrm{h}) / 4 \\
\mathrm{~T}(\text { Total hydrogen })=[(\mathrm{k}+\mathrm{j}+\mathrm{I}+\mathrm{h}+\mathrm{g}+\mathrm{f}+\mathrm{e}+\mathrm{d}+\mathrm{c}+\mathrm{b}+\mathrm{a}) / \mathrm{Ap}] \\
\mathrm{V}(\text { Total vinyl })=[(\mathrm{k}+\mathrm{j})-\mathrm{Ap}] / \mathrm{Ap} \\
\text { Ro.a }(\text { Olefinic/Aliphatic relation })=\mathrm{V} /(\mathrm{a}+\mathrm{b}) \\
\text { Iodine index }=126.91 \times 100 \times \mathrm{V} / \mathrm{MM} \\
\text { Acid index }=3.0597 \times(\text { Ro.a })^{2}-6.3181 \times(\text { Ro.a })+3.3381 \\
\text { Saponification index }=398.42-(\mathrm{MM} \times 0.2358)
\end{gathered}
$$

For the determination of the elements by ICP-OES, the digestion of the samples was performed using concentrated nitric acid, 30\% hydrogen peroxide, and a microwave oven heating. The equipment used was the Atomic Emission Spectrometer with Inductively Coupled Plasma (ICP-OES, Radial) of Spectro Brand, Arcos model, from the Analytical Center of the University of São Paulo (USP).

\section{Results and Discussion}

The yield of the tucumã pulp oil made by the chemical extraction process with hexane solvent was calculated from the ratio of the arithmetic mean of oil mass extracted from the three samples by the arithmetic mean of pulp mass of the fruit. Consequently, obtaining a percentage of $54.70 \%$ extracted oil, according to Table 1.

Table 1. Description of pulp mass and extraction oil of each sample

\begin{tabular}{llll}
\hline Fruit Pulp & Sample 1 & Sample 2 & Sample 3 \\
\cline { 2 - 2 } & $33.66 \mathrm{~g}$ & $36.22 \mathrm{~g}$ & $36.68 \mathrm{~g}$ \\
Extracted oil Mass & $17.87 \mathrm{~g}$ & $20.29 \mathrm{~g}$ & $20.18 \mathrm{~g}$ \\
\hline
\end{tabular}

Source: Search data (2017).

The tucumã pulp oil of the A. aculeatum species presents 10 types of fatty acids among which they have a content of the following most representative acids: palmitic acid (10.4\%), oleic acid (64.2\%), linoleic acid (11\%), stearic acid (4.9\%) and linolenic acid (1\%), as can be seen in Table 2. 
Table 2. Profile of tucumã pulp oil fatty acids

\begin{tabular}{lll}
\hline Fatty Acids & $\mathrm{RT} / \mathrm{min}$ & $\%$ \\
\hline Lauric Acid (C12:0) & 5.1 & 0.2 \\
Myristic Acid (C14:0) & 7.8 & 0.5 \\
Palmitic Acid (C16:0) & 10.4 & 10.4 \\
Margaric Acid (C17:0) & 11.6 & 1.7 \\
Stearic Acid (C18:0) & 12.8 & 4.9 \\
Oleic Acid (C18:1) & 13.0 & 64.2 \\
Linoleic Acid (C18:2) & 13.5 & 11.0 \\
Linolenic Acid (C18:3) & 14.2 & 1.0 \\
Arachidonic Acid (C20:0) & 15.1 & 0.4 \\
Behenic Acid (C22:0) & 17.2 & 0.1 \\
\hline Others & & 5.6 \\
Total & & 100 \\
\hline Saturated fatty acids & & 23.8 \\
Unsaturated fatty acids & & 76.2 \\
\hline
\end{tabular}

Source: Search data (2017).

The result obtained in this study indicates that the oil extracted from the tucumã fruit pulp presents a mean of $23.8 \%$ of saturated fatty acids, $76.2 \%$ of unsaturated fatty acids. Oleic acid showed to be the majority, representing an average value of $64.2 \%$. Palmitic acid was the main representative of saturated acids, with a mean of $10.4 \%$ of the total composition next to the value given by Bora et al. (2000) with $13.86 \%$.

From the nutritional point of view, reported by Ferreira et al. (2008), tucumã oil showed the a more adequate characteristic for food consumption such as cooking oil, fried food and margarine formulation due to its composition of saturated (23.8\%) and unsaturated (76.2\%) fatty acids.

The Amazonas tucumã is an oleaginous that deserves our attention due to the fact of being composed by essential fatty acids that are beneficial to the human being health. Thus, by comparing the fatty acid content between the species studied and the species A. vulgare, for example, it was possible to observe, according to Table 3.

Table 3. Composition of the main fatty acids (\%) of oil extracted from the pulp, according to some researched authors

\begin{tabular}{llll}
\hline Fatty Acids & $\begin{array}{l}\text { Composition by } \\
\text { Bora et al. (2000) }\end{array}$ & $\begin{array}{l}\text { Composition by } \\
\text { Ferreira et al. (2008) }\end{array}$ & $\begin{array}{l}\text { Composition by } \\
\text { Search data (2017). }\end{array}$ \\
\hline Capric acid & & $0.8 \%$ & \\
Palmitic acid & $13.86 \%$ & $22.9 \%$ & $10.4 \%$ \\
Stearic acid & $9.8 \%$ & $2.95 \%$ & $4.9 \%$ \\
Oleic acid & $46.81 \%$ & $67.62 \%$ & $64.2 \%$ \\
Linoleic acid & $26.13 \%$ & $1.15 \%$ & $11.0 \%$ \\
Linolenic acid & $0.93 \%$ & & $1.0 \%$ \\
\hline
\end{tabular}

Source: Search data (2017).

It is possible to verify that the A. aculeatum species, native in Roraima state (Linhares et al., 2017) has a similar brief characteristic regarding the chemical composition of fatty acids of the $A$. vulgare MART species, native in Pará state (Ferreira et al., 2008), and the fruit native in Amazonas state (Bora et al., 2000). This is due to the characteristics of the geographic space, the climatic issues and the geological structure of the soil of each region.

The physicochemical properties were calculated from the integrations of the a, b, c, d, e, f, g, h, i, j and k signal areas, according to Figure 1 and using equations from items 1 to 7, Reda (2006), previously presented in the materials and methods of this study. 


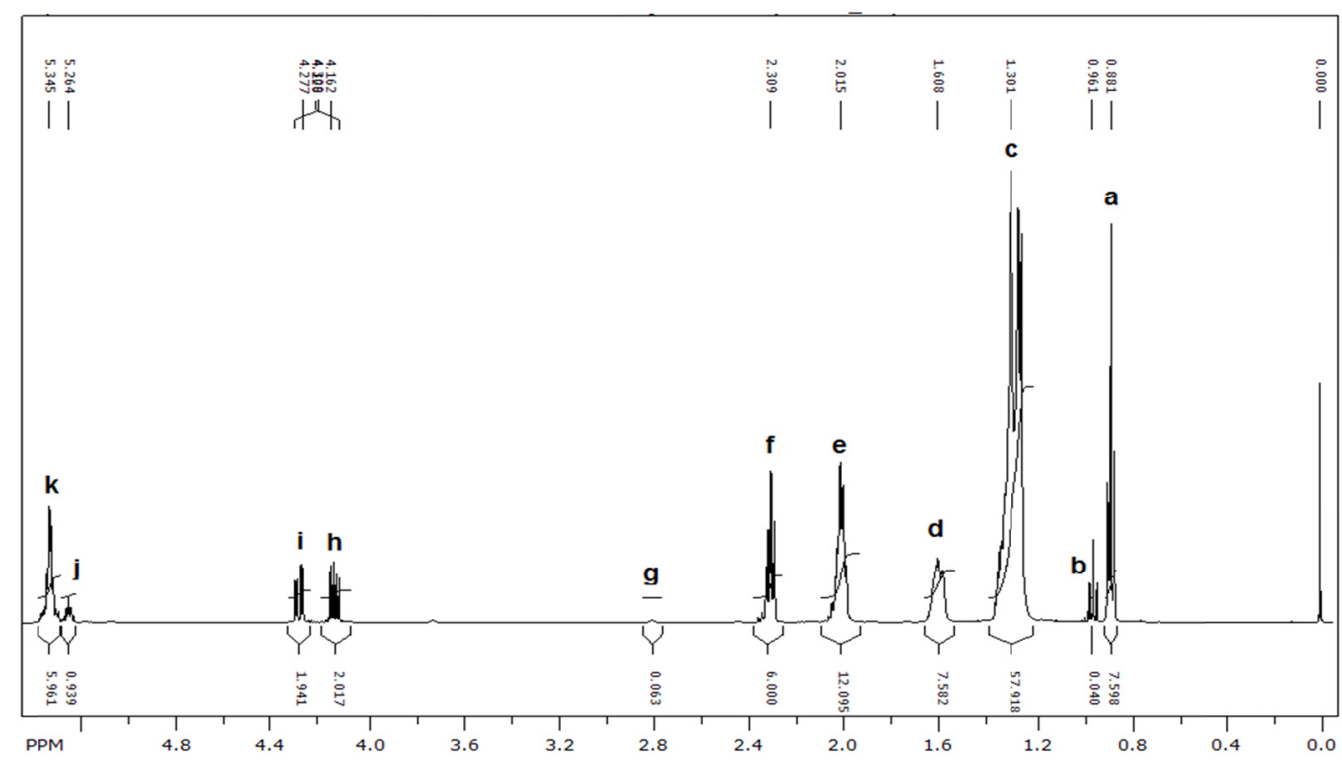

Figure 1. ${ }^{1} \mathrm{H}$ NMR spectrum of the tucumã pulp oil

The "a" sign represents methyl protons; "b" methyl protons of linolenic acid; "c" methylene protons of triacylglycerol fatty acids; "d" beta-carboxylic protons; "e" external allylic protons; "f" alpha-carboxylic protons; "g" internal allylic protons; "h" methylene protons of glycerol; "i" methylene protons of glycerol; " $\mathrm{j}$ " $\mathrm{H}-2$ methylene protons of glycerol; and "k" olefinic protons.

The application of the equations proposed by Reda (2006), items from 1 to 7 , showed the following values:

Ap $($ Proton area $)=(\mathrm{i}+\mathrm{h}) / 4=0.99$

$\mathrm{T}($ Total hydrogen $)=[(\mathrm{k}+\mathrm{j}+\mathrm{i}+\mathrm{h}+\mathrm{g}+\mathrm{f}+\mathrm{e}+\mathrm{d}+\mathrm{c}+\mathrm{b}+\mathrm{a}) / \mathrm{Ap}]=103.29$

$\mathrm{V}($ Total vinyl $)=[(\mathrm{k}+\mathrm{j})-\mathrm{Ap}] / \mathrm{Ap}=5.97$

Ro.a (Olefinic/aliphatic relation) $=\mathrm{V} /(\mathrm{a}+\mathrm{b})=0.78$

Iodine index $=126.91 \times 100 \times \mathrm{V} / \mathrm{MM}=85.97 \mathrm{mg} \mathrm{I}_{2} \mathrm{~g}^{-1}$

Acid index $=3.0597 \times(\text { Ro. })^{2}-6.3181 \times($ Ro.a $)+3.3381=0.31 \mathrm{mg} \mathrm{KOH} \mathrm{g}^{-1}$

Saponification index $=398.42-\left(\mathrm{M}_{\mathrm{W}} \times 0.2358\right)=190.39 \mathrm{mg} \mathrm{KOH} \mathrm{g}^{-1}$

In relation to the acid number, the value found for the oil was $0.31 \mathrm{mg} \mathrm{KOH} \mathrm{g}^{-1}$. According to the Resolution RDC N 270 of ANVISA (2005) the free acidity of refined oils and fats is under $0.6 \mathrm{mg} \mathrm{KOH} \mathrm{g}^{-1}$. Therefore, this presented value of the tuсumã pulp oil is an acid value inferior to the stipulated for refined oils and fats according to ANVISA.

According to description of calculations above, the saponification index is $190.39 \mathrm{mg} \mathrm{KOH} \mathrm{g}^{-1}$. This index is closely linked to the molecular mass of triglycerides. Thus, the lower this index is, the higher will be its molecular mass. For the tucumã pulp oil, the value of saponification indices, were within the parameters established by the Brazilian legislation (Vasconcelos, 2010), between the 190-209 interval.

With regard to the iodine index that measures the degree of fatty acid instauration in vegetable oils, it is evident that the greater the unsaturation of the fatty acids present in the triglyceride molecules, the greater its capacity to absorb iodine and consequently the higher the value of the iodine index. According to Graça (2010), the National Petroleum Agency does not establish a limit for this index. The values for the iodine index above 135 lead to the production of an unacceptable biodiesel, which has nothing to do with the result obtained with the tucumã pulp oil that was of $85.97 \mathrm{mg}$ of $\mathrm{I}_{2} \mathrm{~g}^{-1}$. The value of the relative density of the oil extracted from the tucumã was 0.874 $\mathrm{g} \mathrm{mL}^{-1}$ and the value of the melting point of $17.3^{\circ} \mathrm{C}$

In addition, minerals were identified in the tucumã pulp oil by means of a semi-quantitative scan, obtaining minerals with concentration less than $1 \mathrm{mg} \mathrm{L}^{-1}$ : $\mathrm{Ag}, \mathrm{Al}, \mathrm{B}, \mathrm{Ba}, \mathrm{Cd}, \mathrm{Co}, \mathrm{Cr}, \mathrm{Cu}, \mathrm{Fe}, \mathrm{Li}, \mathrm{Mn}, \mathrm{Ni}, \mathrm{Pb}, \mathrm{Sr}, \mathrm{Zn}$; Elements with concentration between 1 and $100 \mathrm{mg} \mathrm{L}^{-1}: \mathrm{Ca}, \mathrm{Mg}, \mathrm{Na}, \mathrm{P}, \mathrm{S}, \mathrm{Si}$; and mineral with concentration 
above $100 \mathrm{mg} \mathrm{L}^{-1}: \mathrm{K}$. In order to identify metals in the sample with higher concentration, it was decided to quantify, according to Table 4.

Table 4. Quantification of the tucumã pulp oil major metals by ICP-OES

\begin{tabular}{llll}
\hline Element & Result $1\left(\mathrm{mg} \mathrm{L}^{-1}\right)$ & Result $2\left(\mathrm{mg} \mathrm{L}^{-1}\right)$ & Average $\left(\mathrm{mg} \mathrm{L}^{-1}\right)$ \\
\hline $\mathrm{Ca}$ & 15.52 & 24.75 & 20.13 \\
$\mathrm{~K}$ & 68.95 & 71.15 & 70.05 \\
$\mathrm{Mg}$ & 2.61 & 3.04 & 02.83 \\
$\mathrm{Na}$ & 30.35 & 30.26 & 30.30 \\
$\mathrm{P}$ & 20.50 & 19.64 & 20.07 \\
$\mathrm{~S}$ & 4.61 & 4.79 & 4.70 \\
$\mathrm{Si}$ & $<0.04$ & $<0.04$ & $<0.04$ \\
Total & 142.55 & 153.65 & 148.10 \\
\hline
\end{tabular}

Source: Search data (2017).

The highest concentration minerals were $\mathrm{K}, \mathrm{Na}, \mathrm{Ca}$ and $\mathrm{P}$, respectively. The tucumã pulp, therefore, is an important natural food for human health with main sources of minerals for the organism.

\section{Conclusion}

Through the study conducted, it was possible to conclude that the pulp has a high chemical extraction rate of oil with $54.7 \%$, compared to other oil seeds. The oil is rich in omega 9 presenting $64.2 \%$, followed by omega 6 $(11 \%)$ and then omega $3(1 \%)$ which are essential in human nutrition. Regarding the physicochemical properties determined by ${ }^{1} \mathrm{H}$ NMR: acid value of $0.31 \mathrm{mg} \mathrm{KOH} \mathrm{g}^{-1}$, saponification index of $190.39 \mathrm{mg} \mathrm{KOH} \mathrm{g}^{-1}$, and iodine index of $85.97 \mathrm{mg} \mathrm{g}^{-1}$ of the pulp oil is within acceptable standards by the available literature. In addition, it has a value below 135 that lead to the production of biodiesel, according to ANP standards. It is also an important source of food for human health, since they contain several essential minerals such as $\mathrm{Na}, \mathrm{K}, \mathrm{P}$ and $\mathrm{Ca}$. The tucumã of the Amazon, A. aculeatum, is an oleaginous that deserves our attention because it is composed of essential fatty acids that are beneficial to the health of the man and the pulp of the fruit of the tucumã present a high index of chemical extraction.

\section{Acknowledgements}

Federal Institute of Roraima, Federal University of Roraima, Federal University of Minas Gerais, especially Dra. Vanny P. Ferraz for the analysis of gas chromatography of the oil and the Oleoquimicos group for supporting the development of the research.

\section{References}

ANVISA. (2005). Resolution RDC No. 270 of September 22, 2005 of the National Agency of Sanitary Surveillance-ANVISA. Technical regulation for oils in 83 vegetables, vegetable fats and vegetable cream. DOU-Official Journal of the Union: ANVISA.

Bora, P. S., Narain, N., Rocha, R.V. M., Monteiro, A. C. O., \& Moreira, R. A. (2001). Characterisation of the oil and protein fractions of tucuma (Astrocaryum vulgare Mart.) fruit pulp and seed kernel. Ciencia e Tecnologia de Alimentos, 3(2), 111-116. https://doi.org/10.1080/11358120109487654

Calvacante, P. B. (2010). Edible Fruits of the Amazon (7th ed., p. 282). Belém: Paraense Emílio Goeldi Museum.

Christie, W. W. (1989). Gas Chromatography and Lipids - A Practical Guide. The Oily Press, Ayr, Scotland.

Cymerys, M., \& Ferreira, E. (2017). Inajá, Maximiliana maripa (Aubl.) Drude: Fruit and Useful Plants in Amazon Life. Retrieved October 20, 2017, from http://www.cifor.org/publications/pdf_files/books/bshanley 1001/195_202.pdf

Ferreira, E. S., Lucien, V. G., Amaral, A. S., \& Silveira, C. D. S. (2008). Physico-chemical characterization of fruit and oil extracted from tucumã (Astrocaryum vulgare Mart). Alim. Nutr. Araraquara, 19(4), 427-433.

Graça, C. M. M. (2010). Determination of the iodine content from the composition of the oils (Dissertation, Master in Chemistry, University of Aveiro, Portugal).

Hilditch, T. P. (1941). The chemical constitutions of natural fats (p. 438). London, Chapman \& Hall. 
Instituto Adolfo Lutz (IAL). (2008). Physicochemical methods for food analysis (p. 1022). Odair Zenebon, Neus Sadocco Pascuet and Paulo Tiglea Coordinators, São Paulo.

Pesce, C. (2009). Oleaginous of Amazônia (2nd ed., p. 334). Belém: Paraense Emílio Goeldi Museum; Brasília: Ministry of Agrarian Development.

Reda, S. Y. (2004). Comparative study of vegetable oils subjected to thermal stress (p. 153, Dissertation, Master in Chemistry, Estadual University of Ponta Grossa, Ponta Grossa).

Reda, S. Y., \& Carneiro, P. I. B. (2006). Oils and fats: Applications and implications. Analytica, 27, 60-67.

Santos, R. C., Melo Filho, A. A., Chagas, E. A., Takahashi, J. A., Ferraz, V. P., Costam, A. K. P., ... Ribeiro, P. R. E. (2015). Fatty acid profile and bioactivity from Annona hypoglauca seeds oil. African Journal of Biotechnology, 14(30), 2377-2382. https://doi.org/10.5897/AJB2015.14714

Shanley, P., Serra, M., \& Medina, G. (2010). Fruit and Useful Plants in Amazon Life (2nd ed.). Revista and Expanded.

Vasconcelos, B. E. C. (2010). Evaluation of the physical, chemical and nutritional characteristics of tucumã oils (Astrocaryum aculeatum and Astrocaryum vulgare) obtained with $\mathrm{CO}_{2}$ pressurized (p. 103, Master of Dissertation in Food Science and Technology, Institute of Technology, Federal University of Pará).

\section{Copyrights}

Copyright for this article is retained by the author(s), with first publication rights granted to the journal.

This is an open-access article distributed under the terms and conditions of the Creative Commons Attribution license (http://creativecommons.org/licenses/by/4.0/). 